\title{
Effects of Different Metals on Photosynthesis: Cadmium and Zinc Affect Chlorophyll Fluorescence in Durum Wheat
}

\author{
Momchil Paunov ${ }^{1}$, Lyubka Koleva ${ }^{2}$, Andon Vassilev ${ }^{2, *}$, Jaco Vangronsveld ${ }^{3}$ \\ and Vasilij Goltsev ${ }^{1}$ \\ 1 Department of Biophysics and Radiobiology, Faculty of Biology, Sofia University, 1164 Sofia, Bulgaria; \\ mokavey@abv.bg (M.P.); goltsev@biofac.uni-sofia.bg (V.G.) \\ 2 Department of Plant Physiology and Biochemistry, Agricultural University, 4000 Plovdiv, Bulgaria; \\ 1_koleva2001@yahoo.com \\ 3 Centre for Environmental Sciences, Hasselt University, 3590 Diepenbeek, Belgium; \\ jaco.vangronsveld@uhasselt.be \\ * Correspondence: andon.vasilev@abv.bg
}

Received: 15 January 2018; Accepted: 7 March 2018; Published: 9 March 2018

\begin{abstract}
A comparative study of the effects of exposure to high $\mathrm{Cd}^{2+}(50 \mu \mathrm{M})$ and excess $\mathrm{Zn}^{2+}$ $(600 \mu \mathrm{M})$ on photosynthetic performance of hydroponically-grown durum wheat seedlings was performed. At day 8, Cd and $\mathrm{Zn}$ were added to the nutrient solution. After 7-days exposure, the chosen concentrations of both metals resulted in similar relative growth rate (RGR) inhibitions of about $50 \%$ and comparable retardations of the $\mathrm{CO}_{2}$ assimilation rates (about $30 \%$ ) in the second developed leaf of wheat seedlings. Analysis of chlorophyll a fluorescence indicated that both metals disturbed photosynthetic electron transport processes which led to a 4- to 5-fold suppression of the efficiency of energy transformation in Photosystem II. Non-specific toxic effects of $\mathrm{Cd}$ and $\mathrm{Zn}$, which prevailed, were an inactivation of part of Photosystem II reaction centres and their transformation into excitation quenching forms as well as disturbed electron transport in the oxygen-evolving complex. The specificity of the $\mathrm{Cd}$ and $\mathrm{Zn}$ modes of action was mainly expressed in the intensity of the toxicity effects: despite the similar inhibitions of the $\mathrm{CO}_{2}$ assimilation rates, the wheat photochemistry showed much more sensitivity to $\mathrm{Cd}$ than to $\mathrm{Zn}$ exposure.
\end{abstract}

Keywords: photosynthesis; chlorophyll fluorescence; cadmium; zinc

\section{Introduction}

Metal contamination is one of the most important environmental problems. It is mostly due to industrial and agricultural activities, such as smelter and incinerator emissions, traffic, dispersal of mining wastes, use of contaminated sewage sludges, manures, phosphate fertilizers, etc. [1,2]. Cadmium $(\mathrm{Cd})$ and zinc $(\mathrm{Zn})$ are among the most problematic metals, creating potential risks for both plant production and animal and human health.

Most studies on plant-metal interactions are focused on the processes involved in metal ion uptake and accumulation in the harvestable crop parts as well as on metal-induced phytotoxicity. Cadmium has no known biological functions, but is easily taken up by plants [3,4]. From plants, it may accumulate into food chains, where it may, for example, cause harmful effects on human health. Yet there exist a few reports demonstrating a possible biological role of $\mathrm{Cd}$ in plants: as a substitute for $\mathrm{Zn}$ in the $\mathrm{Zn} / \mathrm{Cd}$ hyperaccumulator Sedum alfredii [5] as well as a feeding deterrent against Frankliniella occidentalis (thrips) in the hyperaccumulator Thlaspi caerulescens ([6] and references therein). Cadmium may also provoke significant phytotoxic effects even in relatively low tissue 
concentrations (micro-element range). Different from $\mathrm{Cd}, \mathrm{Zn}$ is an essential element for all plants, but excess $\mathrm{Zn}$ induces functional disorders in plants. The phytotoxicity threshold for $\mathrm{Zn}$ concentrations in plant tissues are in the range of $200-500 \mathrm{mg} \mathrm{kg}^{-1}[7,8]$.

The visible toxicity symptoms in $\mathrm{Cd}$ - and $\mathrm{Zn}$-exposed plants are similar: inhibited germination, stunted growth, leaf chlorosis, necrotic spots, etc. $[9,10]$. The described toxic effects of both metals on cardinal physiological processes in plants, such as photosynthesis, water relations, mineral nutrition, dark respiration, etc. are also comparable [11-16]. For example, it has been shown that both metals can induce similar or identical disturbances of photosynthesis at different structural-functional levels: pigments and light capture, thylakoid ultrastructure and photosynthetic electron transport, stomatal conductance and access of $\mathrm{CO}_{2}$, activities of Calvin cycle enzymes, etc. [11,17-19].

Cadmium and Zn-induced effects in the light-dependent photosynthetic processes have been studied in both in vitro and in vivo conditions [20-23]. In in vitro studies, it was established that both metals can significantly decrease the activities of photosystem II (PSII) and, to lesser extent, also of photosystem I (PSI) as well as the rate of photosynthetic electron transport $[17,24]$. However, in vivo studies obtained by chlorophyll $a$ fluorescence (ChlF) techniques repeatedly reported that the photochemical reactions are not so sensitive to $\mathrm{Cd}$ and $\mathrm{Zn}$ than Calvin's cycle reactions $[19,25,26]$. Partially, this inconsistency could be explained by the fact that in vitro studies are performed without substrate limitation and occurrence of feedback inhibition, while in vivo the metal-induced alterations in primary $C$ metabolism may lead to a down-regulation of PSII activity $[21,25,27]$. Hence, the effects of high $\mathrm{Cd}$ and excess $\mathrm{Zn}$ concentrations on the light-dependent photosynthetic processes are still not fully understood.

The most common and widely used ChlF analyses are performed on dark- and light-adapted leaf samples, and subsequently different parameters characterizing the steady-state status of the photosynthetic apparatus are calculated [28]. More recently, the so-called JIP-test was introduced in chlorophyll fluorescence analyses [29]. The JIP-test is based on measurements of ChlF fast kinetics and on analysis of signals providing detailed information on the structure and function of the photosynthetic apparatus (PSA), primarily PSII. The models underlying the JIP-test describe the primary photosynthetic reactions by taking into account the structure of PSA in full consistency with the theory of energy fluxes occurring in the thylakoid membrane between the complexes of photosynthetic pigments in PSII $[30,31]$. In the past few years, this test was widely used for plant performance testing under stressful conditions [31-34]. For example, it has been applied for the evaluation of plant performance under conditions of light [35], chilling [36,37], high temperature [38-40], and drought [41-44] stress. More recently, the JIP test was also applied to evaluate the photosynthetic performance of plants exposed to different metals [45-48]. Unfortunately, until now, the JIP-test information published for plants exposed to excess $\mathrm{Zn}$ is very scant. The available JIP-test information for Cd-exposed maize plants was obtained in conditions that did not induce growth inhibition [48].

Despite the relatively rich dataset concerning effects of high $\mathrm{Cd}$ and excess $\mathrm{Zn}$ concentrations on plant performance, it is obvious that there are still many open questions. For example, it is still not clear enough whether these metals may cause specific effects on photosynthesis or not. Considering the fact that the biological functions of these metals are completely different, it is reasonable to expect their impact on plant performance also to differ. Unfortunately, comparative studies on Cd- and Zn-induced phytotoxicity effects are scarce. Considering the lack of sufficient and detailed information concerning in vivo measured effects of $\mathrm{Cd}$ and $\mathrm{Zn}$ on primary photosynthetic processes, we decided to perform a comparative study. To compare the phytotoxic effects of non-essential (Cd) and essential ( $\mathrm{Zn})$ elements, our experimental design consisted of exposing plants to external $\mathrm{Cd}$ and $\mathrm{Zn}$ concentrations that produced identical inhibition of plant growth.

\section{Results}

The wheat seedlings exposed to $50 \mu \mathrm{M} \mathrm{Cd}^{2+}$ and $600 \mu \mathrm{M} \mathrm{Zn}^{2+}$ in the medium manifested clear toxicity symptoms, such as the appearance of chlorotic and necrotic leaf spots, weaker development of 
side roots, and root browning $[2,10]$. There were some differences in the visible toxicity symptoms in the leaves of $\mathrm{Zn}$ - and Cd-exposed plants. While $\mathrm{Zn}$ caused necrotic spots, $\mathrm{Cd}$ induced chlorosis. Exposure to $\mathrm{Cd}$ resulted in browning and a stronger inhibition of root length growth and branching, whereas $\mathrm{Zn}$ exposure lead to roots that were lighter in color and thinner in diameter.

Dry weight increase and RGR of Cd- and Zn-exposed wheat seedlings were inhibited by approximately $50 \%$, while their net photosynthetic rate (A) was about $35 \%$ lower (Table 1 ). The mineral analysis revealed that both $\mathrm{Cd}$ and $\mathrm{Zn}$ concentrations in the roots of exposed plants $\left(936 \mathrm{mg} \mathrm{Cd} \mathrm{kg}{ }^{-1}\right.$ dry weight and $3029 \mathrm{mg} \mathrm{Zn} \mathrm{kg}^{-1}$ dry weight) were several-fold higher than those in the leaves (150 mg $\mathrm{Cd} \mathrm{kg}^{-1}$ dry weight and $880 \mathrm{mg} \mathrm{Zn} \mathrm{kg}^{-1}$ dry weight). Cadmium and $\mathrm{Zn}$ exposure strongly diminished chlorophyll and carotenoid concentrations (Table 2). The decreases of chlorophyll $a$ concentrations due to $\mathrm{Cd}$ and $\mathrm{Zn}$ exposure were higher than $50 \%$, while chlorophyll $b$ was less affected. Cadmium tended to inhibit the chlorophyll $\mathrm{b}$ concentration a bit more than $\mathrm{Zn}$ (although not significant). The total carotenoid concentration was more inhibited by $\mathrm{Zn}$.

Table 1. Effects of $\mathrm{Cd}$ and $\mathrm{Zn}$ on growth parameters (DW—-fresh weight, RGR—relative growth rate) and net photosynthetic rate $(\mathrm{A})$ of durum wheat plants.

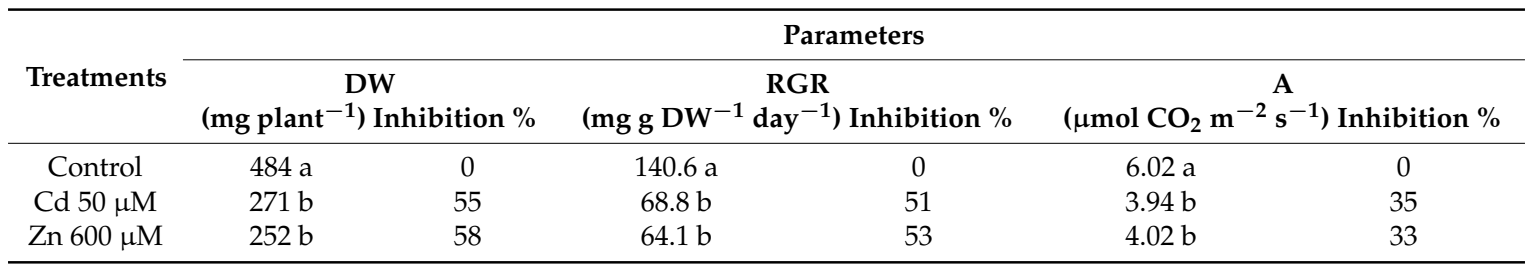

Values followed by different letters $(\mathrm{a}, \mathrm{b})$ within a column are significantly different at $p<0.05$.

Table 2. Effects of $\mathrm{Cd}$ and $\mathrm{Zn}$ on photosynthetic pigments content in durum wheat plants.

\begin{tabular}{ccccccc}
\hline \multirow{2}{*}{ Treatments } & \multicolumn{5}{c}{ Photosynthetic Pigments Content (mg g FW $\mathbf{~}^{-\mathbf{1}}$ ) } \\
\cline { 2 - 7 } & Chlorophyll $\boldsymbol{a}$ & Inhibition \% & Chlorophyll $\boldsymbol{b}$ & Inhibition \% & Carotenoids & Inhibition \% \\
\hline Control & $1.77 \mathrm{a}$ & 0 & $0.70 \mathrm{a}$ & 0 & $0.47 \mathrm{a}$ & 0 \\
$\mathrm{Cd} 50 \mu \mathrm{M}$ & $0.85 \mathrm{~b}$ & 52 & $0.48 \mathrm{~b}$ & 31 & $0.32 \mathrm{~b}$ & 32 \\
$\mathrm{Zn} 600 \mu \mathrm{M}$ & $0.80 \mathrm{~b}$ & 55 & $0.53 \mathrm{~b}$ & 24 & $0.26 \mathrm{c}$ & 45 \\
\hline
\end{tabular}

Values followed by different letters $(\mathrm{a}, \mathrm{b}, \mathrm{c})$ within a column are significantly different at $p<0.05$.

The similar inhibitions of both RGR and A in Cd- and Zn-exposed wheat seedlings provided a good opportunity to compare the toxic effects of these metals more in detail.

The state of the light-dependent photosynthetic processes in Cd- and Zn-exposed wheat plants was analyzed applying the JIP test. This approach allows monitoring of molecular processes occurring at the level of the photosynthetic machinery during the light phase in leaves: energy migration between neighboring photosynthetic units and electron transfer reactions at donor and acceptor sites of both PSII and PSI and between them $[49,50]$. The induction curves of chlorophyll fluorescence recorded for $1 \mathrm{~s}$ in dark-adapted plants are shown in Figure 1A. The increase of the initial chlorophyll fluorescence level $\left(\mathrm{F}_{\mathrm{O}}\right)$, the decrease of the maximal level $\left(\mathrm{F}_{\mathrm{M}}\right)$, and the change of the transient's shape are clearly visible in the exposed plants compared to the non-exposed control. All these effects show that the photosynthetic process is strongly affected by metal exposure. The $\mathrm{F}_{\mathrm{O}}$ rise indicates decreased energy trapping efficiency of PSII. The reduced efficiency of the energy transfer from the antenna to the RC was demonstrated by Havaux [51] and Yamane et al. [52] for heat-stressed photosynthesizing leaves. The former could be due to the metals disturbing the structure of the RC complexes and the latter because of swelling of the thylakoid membranes due to hygroscopic or charge shielding action of the divalent metal ions leading to a pulling apart of the complexes, lowering the energy transfer efficiency. The measured maximal level of chlorophyll fluorescence $\left(\mathrm{F}_{\mathrm{M}}\right)$ is a complex parameter that is dependent on the structural leaf tissue characteristics determining actinic light absorption, reflection, and reabsorption of emitted chlorophyll fluorescence including the chlorophyll content 
in the leaf (see [31] and the references therein). The $\mathrm{F}_{\mathrm{M}}$ decline could be partly related to a reduced chlorophyll $a$ concentration which is observed in metal exposed plants (Table 2). The presence of chlorophyll fluorescence quenchers could lower $F_{M}$ as well. Such molecules could be endogenous like carotenoids or exogenous like oxygen. However, in exposed plants the carotenoid contents decreased. Although, it is well known that under strong stress the chlorophyll molecules become more easily accessible to oxygen and other exogenous quenchers. The assumptions made above are well supported by the values of the main JIP parameters (Figure 1B). Each parameter is explained in Table 3. There were statistically significant differences between $\mathrm{Cd}$-exposed and non-exposed control plants for all parameters and for all but $\mathrm{F}_{\mathrm{M}}, \mathrm{N}, \mathrm{RC} / \mathrm{CS}_{0}$, and $\phi_{\mathrm{Ro}}$ parameters in the case of $\mathrm{Zn}$-exposed plants.

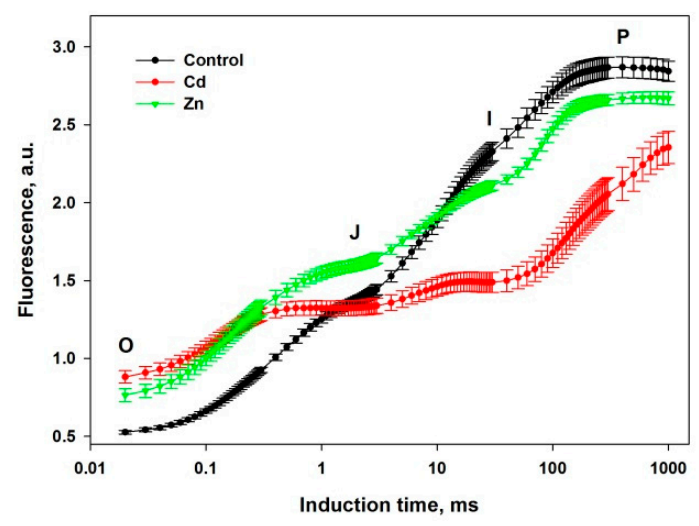

(A)

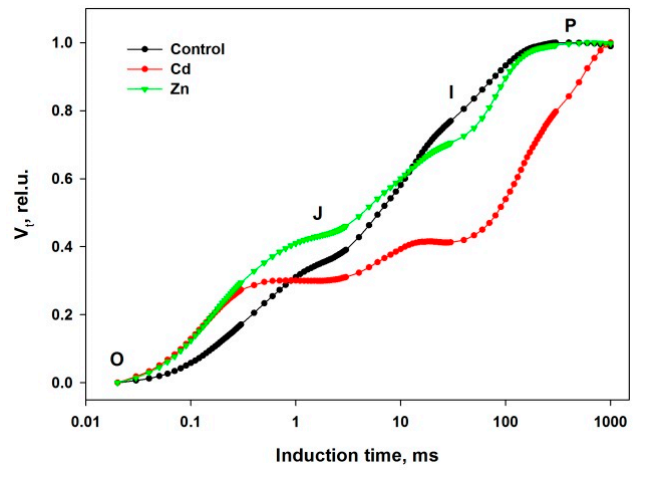

(C)

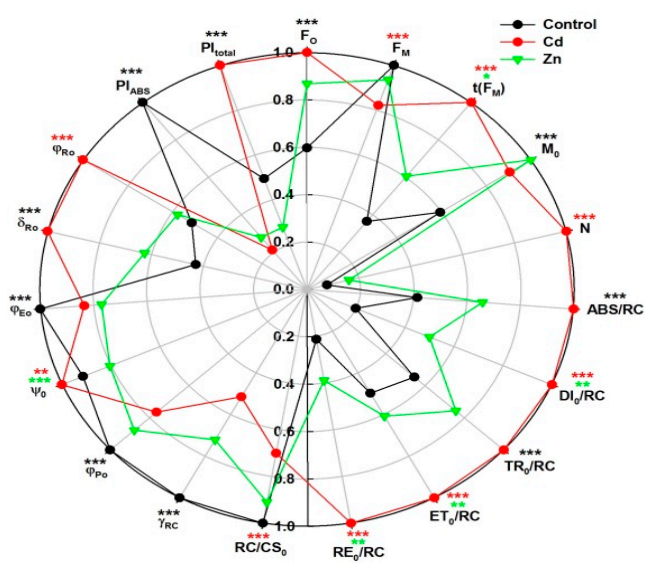

(B)

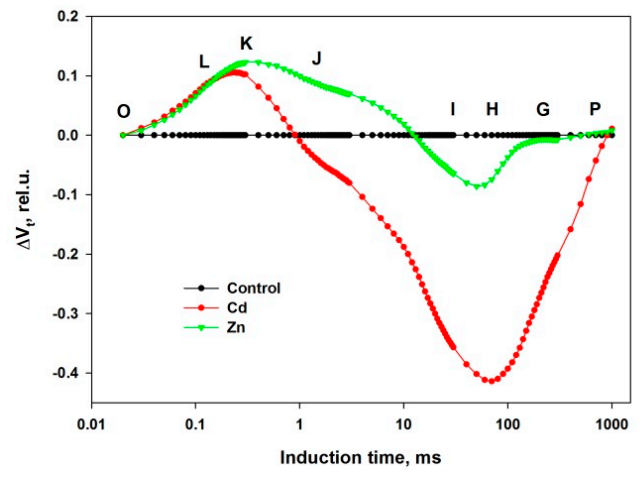

(D)

Figure 1. (A) Induction transients of chlorophyll $a$ fluorescence in leaves of wheat (Triticum durum Desf. (cv. Beloslava)) plants—control (black), exposed to $50 \mu \mathrm{M} \mathrm{Cd}$ (red) and $600 \mu \mathrm{M} \mathrm{Zn} \mathrm{(green).} \mathrm{The} \mathrm{whole}$ plants were adapted to dark in room for $1 \mathrm{~h}$ and additionally the measured spots were kept in dark in the clip for $1 \mathrm{~min}$ just before measurement. Induction curves of ChlF were recorded for $1 \mathrm{~s}$ with $3000 \mu \mathrm{mol} \mathrm{m}{ }^{-2} \mathrm{~s}^{-1}$ PPFD. Each point in the graph is an averaged value of 6 repetitions and the standard errors are shown. The characteristic levels $(\mathrm{O}, \mathrm{J}, \mathrm{I}$, and $\mathrm{P})$ of the induction transients are denoted with letters. (B) Parameters of the JIP test (described in Table 1) are calculated from the curves shown in A. The asterisks above each parameter indicate if there is statistical significance for the Cd (red) or $\mathrm{Zn}$ exposure (green) or for both treatments (black): 1 asterisk $-p<0.05,2-p \leq 0.01$, and $3-p \leq 0.001$. (C) Induction curves of the relative variable chlorophyll fluorescence $\left(\mathrm{V}_{t}\right)$ resulting from double normalization of the values in $(A)$ to the minimal $\left(\mathrm{F}_{\mathrm{O}}\right)$ and maximal $\left(\mathrm{F}_{\mathrm{M}}\right)$ levels. The characteristic levels $(\mathrm{O}, \mathrm{J}, \mathrm{I}$, and $\mathrm{P})$ of the induction curves are denoted as in (A). (D) Curves of differential values $\left(\Delta \mathrm{V}_{\mathrm{t}}\right)$ resulting from subtracting the control from exposed $\mathrm{V}_{\mathrm{t}}$. The times of the induction curves characteristic levels $(\mathrm{O}, \mathrm{J}, \mathrm{I}$, and $\mathrm{P})$ are marked as well as the intermediary levels $(\mathrm{L}, \mathrm{K}, \mathrm{H}$, and $\mathrm{G})$ at which $\Delta \mathrm{V}_{\mathrm{t}}$ peaks and shoulders occur. 
To better analyze the differences in the induction curve's shape, the transients of the double normalized fluorescent signal (to $\mathrm{F}_{\mathrm{O}}$ and $\mathrm{F}_{\mathrm{M}}$ ) are presented in Figure 1C. In this way, the deviations in the intermediate induction phases of exposed plants with respect to the control become clear:

- steeper initial rise for both metals,

- increase for $\mathrm{Zn}$, decrease for $\mathrm{Cd}$ of the $\mathrm{V}_{\mathrm{J}}(2 \mathrm{~ms})$, and

- decrease (very strong for $\mathrm{Cd}$ ) of the $\mathrm{V}_{\mathrm{I}}(30 \mathrm{~ms})$.

Noteworthy is the fact that not only are the $\mathrm{V}_{\mathrm{J}}$ and $\mathrm{V}_{\mathrm{I}}$ levels are much lower for Cd-exposed seedlings, but that the rise before and after them is heavily slowed down with chlorophyll fluorescence still rising $1 \mathrm{~s}$ after the start of induction, probably not reaching the real maximal level $\left(\mathrm{F}_{\mathrm{M}}\right)$. This observation could be explained by a high availability of efficient chlorophyll fluorescence quenchers or formation of inactive PSII reaction centers with destroyed oxygen-evolving complex (OEC), that are able to quench a large part of excitation in PSII antennae complexes.

Differential curves resulting from subtracting the control from the $\mathrm{Zn}$ - and Cd-exposed double normalized fluorescent values are presented in Figure 1D. Thus the 3 bullet points outlined above can be visualized as:

- positive peak in $\mathrm{F}_{\mathrm{O}}-\mathrm{F}_{\mathrm{J}}$,

- shoulder in $\mathrm{F}_{\mathrm{J}}-\mathrm{F}_{\mathrm{I}}$ and

- $\quad$ negative peak in $\mathrm{F}_{\mathrm{I}}-\mathrm{F}_{\mathrm{P}}$ transient.

The differential curves constructed in the first and the second time intervals should be connected with excitation energy redistribution between neighboring PSII antenna complexes as well as with the balance of electron transport reactions around PSII. The increased level at $0.3 \mathrm{~ms}$, called the (positive) $\mathrm{K}$-band, is a typical characteristic in the case of high temperature stress, indicating a reduced rate of electron donation to RC due to impaired OEC [53]. On the other side, a K-band could be connected to a higher rate of electron transport from RC to its acceptors. In conclusion, a positive K-band occurs whenever the balance of electron transport around PSII is causing electron deficit and formation of $\mathrm{P}_{680}{ }^{+}$ that is an effective quencher of excited state of chlorophyll molecules $[53,54]$. That molecule is in fact a powerful chlorophyll fluorescence quencher-absorbed light cannot be utilized in photochemistry and dissipates as heat. High levels of $\mathrm{P}_{680}{ }^{+}$may contribute to the striking quenching observed in Cd exposed seedlings.

The increased $\mathrm{F}_{\mathrm{J}}$ level and the shoulder in the $\mathrm{F}_{\mathrm{J}}-\mathrm{F}_{\mathrm{I}}$ transient in the case of $\mathrm{Zn}$ exposure could be connected with a reduced rate of electron transfer from $Q_{A}$ to $Q_{B}$ at the acceptor side of PSII. These effects as well as the positive K-band should lower the photosynthetic electron flow from PSII to PSI. The decreased $\mathrm{F}_{\mathrm{J}}$ level, despite the positive peak in the initial rise of $\mathrm{F}_{\mathrm{O}}-\mathrm{F}_{\mathrm{J}}$ in the case of $\mathrm{Cd}$ exposure, suggests vast quantities of $\mathrm{P}_{680}{ }^{+}$and/or highly effective quenching by exogenous molecules.

The decreased $\mathrm{F}_{\mathrm{I}}$ level and the negative peak in the $\mathrm{F}_{\mathrm{I}}-\mathrm{F}_{\mathrm{P}}$ transient could be connected with a bigger pool of intersystem (plastoquinone) and/or PSI end electron acceptors per active PSII RC in the exposed plants compared to the control.

All the observations described above can be demonstrated more precisely by constructing differential curves within different parts of the induction. Such curves are plotted on Figure 2A-D for 4 different time intervals, representing formation of bands: $\mathrm{L}$ (interval O-K), $\mathrm{K}(\mathrm{O}-\mathrm{J}), \mathrm{H}(\mathrm{J}-\mathrm{I})$, and $\mathrm{G}(\mathrm{I}-\mathrm{P})$.

Positive L, K, and $\mathrm{H}$ bands are seen in Figure 2A-C as well as a negative $\mathrm{G}$ band (Figure 2D) for both metal exposures. However, the effects of $\mathrm{Cd}$ exposure are much more obvious in every case. Interestingly, the times for the extreme of each band are the same for both metals for $\mathrm{L}(120 \mu \mathrm{s})$ and $\mathrm{K}(250 \mu \mathrm{s})$ but they differ slightly for $\mathrm{H}(\mathrm{Zn}-9 \mathrm{~ms}, \mathrm{Cd}-11 \mathrm{~ms})$ and significantly for $\mathrm{G}(\mathrm{Zn}-60 \mathrm{~ms}$, $\mathrm{Cd}-130 \mathrm{~ms})$, demonstrating that the specificity of the $\mathrm{Cd}$ and $\mathrm{Zn}$ effects is exhibited in electron transport after PSII. 


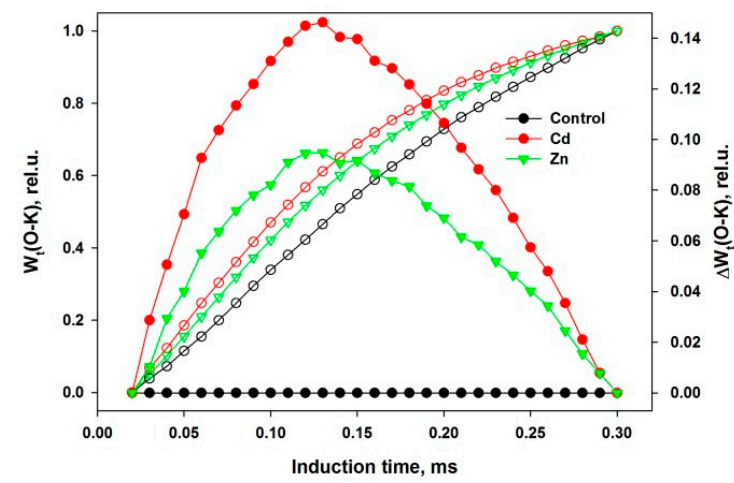

(A)

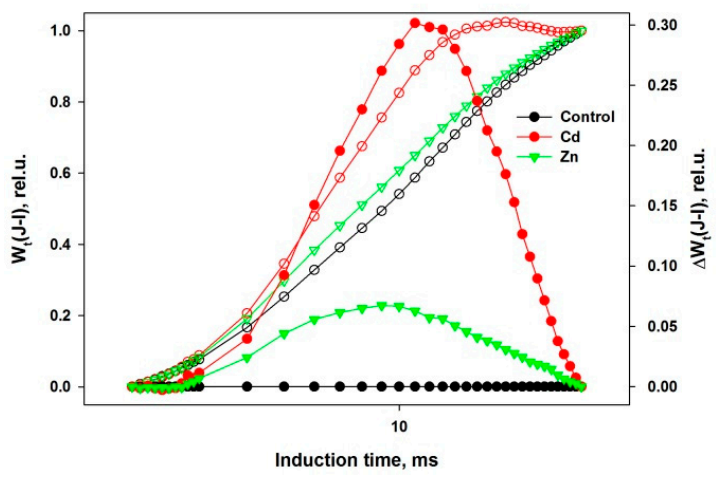

(C)

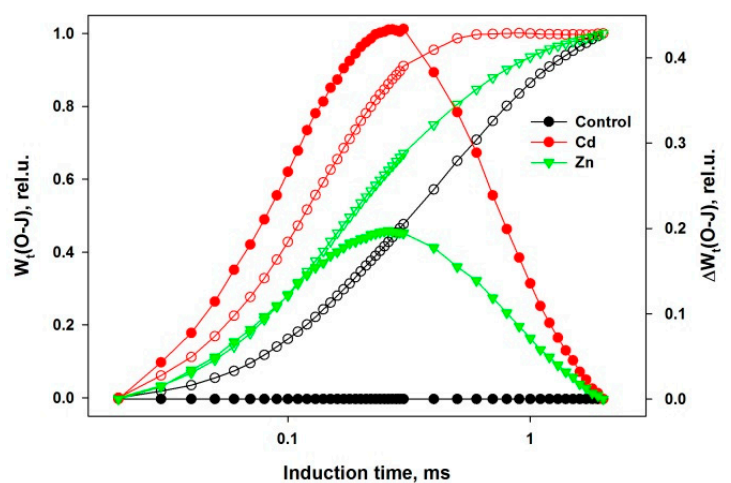

(B)

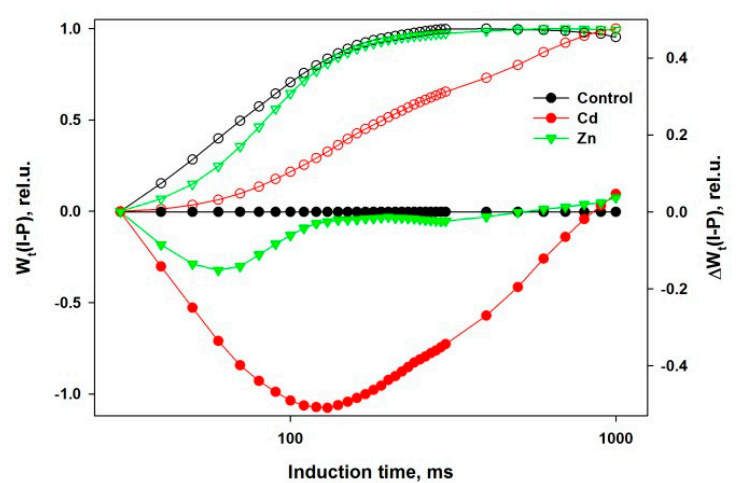

(D)

Figure 2. Combined graphs of differential curves (filled circles) and their corresponding double normalized chlorophyll fluorescence signal (empty circles): (A) from $\mathrm{O}$ to $\mathrm{K}$ (L band), (B) from $\mathrm{O}$ to $\mathrm{J}$ (K band), (C) from J to I (H), and (D) from I to P (G band). All these transients are constructed from the corresponding values of the curves shown in Figure $1 \mathrm{~A}$ and the series designation is the same: control plants (black), exposed to $\mathrm{Cd}$ (red), and to $\mathrm{Zn}$ (green). There is a statistically significant difference for the maximal values of the differential curves of exposed plants compared to the control with $p<0.05$.

\section{Discussion}

To describe the responses of the wheat photosynthetic apparatus to $\mathrm{Cd}$ - and Zn-exposure, we used the analysis of the photoinduced induction transients of chlorophyll fluorescence $[44,49,55]$. The dynamics of the chlorophyll fluorescence rise are directly related to redox reactions not only in PSII, but throughout the entire photosynthetic electron transport chain. The application of the JIP test [56] allows analysis of the changes in important energetic characteristics of the PSA as well as the stress-induced processes in the light phase of photosynthesis under in vivo conditions (Table 3).

Metal exposure disturbs the energy migration from the antenna complexes to the chlorophyll of the reaction centers which leads to an increased chlorophyll fluorescence emission in dark-adapted objects $\left(\mathrm{F}_{\mathrm{O}}\right)$. In this study, $\mathrm{Cd}$ exhibited a much more effective inhibition than $\mathrm{Zn}$ (see Figure $1 \mathrm{~A}$ ). One of the effects is the inactivation of a part of the reaction centers of PSII, which are converted in so-called "energy sinks", thus transforming the excitation energy of the antenna chlorophylls into heat energy. This is demonstrated by the parameters $\gamma_{\mathrm{RC}}$ (representing the relative part of photochemically active molecules, $\mathrm{P}_{680}$, in the total pool of chlorophyll molecules in PSII) and $\mathrm{RC} / \mathrm{CS}_{0}$ (representing the relative concentration of active RC per unit illuminated area). A consequence of this effect is also the changes of the relative antenna size linked to each active RC (represented by the parameter $\mathrm{ABS} / \mathrm{RC}$ ), which increases in metal-exposed wheat plants, particularly in the case of Cd-exposure. The reduced number of active RC leads to an increase of necessary numbers of RC turnovers for full reduction of the plastoquinone pool (parameter $\mathrm{N}$ ). Accordingly, a certain suppression of the RC 
photochemical efficiency is detected, presented by the quantum yield of the primary photochemical reaction $\left(\phi \mathrm{P}_{0}\right)$, while the re-oxidation reaction of the primary quinone acceptor $\mathrm{Q}_{\mathrm{A}}{ }^{-}$is slightly reduced by $\mathrm{Zn}$-exposure and even probably activated in case of Cd-exposure [57].

Generally, the dynamics of the induction transient may be successfully analyzed by plotting of differential curves [56] (see Figure 1D). The stress factors strongly modify the shapes of the differential curves and the effects are manifested in different ways, forming bands of the induction transient. Strasser et al. [56] suggested nomenclature for the designation of different transient phases by the letters (bands) L, K, J, I, H, and G.

For a more detailed characterization of the impact of metal exposure on the PSA of the wheat seedlings, we analyzed the stress-induced changes of the shape of the fast chlorophyll fluorescence rise from the $\mathrm{O}$ to $\mathrm{P}$ phase (Figure 1D) as well as separate sections of the this integral transient in the time course intervals: 20-300 $\mu \mathrm{s}, 20-2000 \mu \mathrm{s}, 2-30 \mathrm{~ms}$, and 30-300 ms.

The shape of the induction curve between 20 and $300 \mu$ s (usually called the $L$ band) is influenced by the excitation energy transfer between PSII units, commonly denoted as "connectivity" or “grouping" [58,59].

The appearance of a positive L band (Figure 2A) indicates a weaker connectivity between adjacent PSIIs at the level of the antenna complexes. This means that $\mathrm{Zn}$ and $\mathrm{Cd}$ also affect the structure of the thylakoid membranes, expressed by a decreased transfer of excitation energy between adjacent photosynthetic units [60]. The changes of the energetic interactions could be a result of stacking/destacking of thylakoid membranes caused by electrostatic interaction at different ion concentrations [61,62].

The $\mathrm{K}$ band occurring during the O-J transient (Figure 2B) is usually explained as a result of an imbalance in electron transfer reactions at donor and acceptor sides of PSII [53]. The appearance of a positive $\mathrm{K}$-band is usually explained as a consequence of a retardation of electron donation from the OEC to oxidized chlorophyll, leading at light to the formation of an increased $\mathrm{P}_{680^{+}}$concentration able to effectively quench the excited antenna chlorophylls. The maximal chlorophyll fluorescence level of the induction curve, reflecting the state of PSA with fully closed PSII RCs, is significantly decreased in Cd-exposed wheat seedlings as compared to the control and even to $\mathrm{Zn}$-exposed ones (see point $\mathrm{P}$ in Figure $1 \mathrm{~A}$ and $\mathrm{F}_{\mathrm{M}}$ in Figure 1B). The appearance of a $\mathrm{K}$ band was also observed at high temperature exposure of PSA and may be due to dissociation of the PsbO protein (Mn stabilizing protein) from the OEC $[63,64]$. The strongly expressed K-band demonstrated that both metals, but especially Cd, disturbed the functioning of OEC in PSII.

The chlorophyll fluorescence rise within the thermal phase of the induction kinetics is rather complex and depends on different factors, which were described in detail in a comprehensive review [50]. A more simplified model describes the induction transient phases by energy fluxes at different stages of the photosynthetic light phase [49]. In the frame of this model, the photoinduced transient from phase J (2 ms) to I $(30 \mathrm{~ms})$ represents the dynamics of the plastoquinone pool reduction between both photosystems. Phase I is formed when a dynamic equilibrium (quasi-steady-state condition) is reached between reduction of the plastoquinone pool by the electron flow originating from PSII and its re-oxidation due to PSI activity. The comparison of the transient dynamics between control (non-exposed) and metal-exposed plants in that time interval indicates that $\mathrm{Cd}$ and $\mathrm{Zn}$ ions influenced both redox reactions. The visible positive band (especially in case of Cd-exposure) (Figure 2C) could reflect a decrease in the relative numbers of active plastoquinone molecules reduced by each active RC of PSII.

During the time interval for the induction transient from I to $\mathrm{P}$, the dynamics are defined by the reduction speed of the terminal electron acceptors in PSI. It could be suggested that the strongly expressed negative bands (see Figure 2D) indicate an increase of the pool of the potential electron acceptors and a general decrease of the linear electron flux through both photosystems.

In conclusion, both $\mathrm{Cd}$ and $\mathrm{Zn}$ had clear negative effects on the plant processes considered in this experiment. However, we found that these metals exhibit specificity concerning their effects on 
PSA of wheat plants in circumstances under which the effects on integral processes were very similar (parameters DW, RGR, A, and chlorophyll content). This specificity was expressed in the intensity of the effect: PSA was much more sensitive to $50 \mu \mathrm{M}$ Cd than to $600 \mu \mathrm{M} \mathrm{Zn}$ exposure.

\section{Materials and Methods}

Seeds of Triticum durum Desf. (cv. Beloslava) were germinated on wet filter paper and the seedlings were transferred to pots filled with nutrient solution with $\mathrm{pH}=5.8 \pm 0.1$ containing: $0.505 \mathrm{mM} \mathrm{KNO}_{3}$, $0.15 \mathrm{mM} \mathrm{Ca}\left(\mathrm{NO}_{3}\right)_{2} \times 4 \mathrm{H}_{2} \mathrm{O}, 0.1 \mathrm{mM} \mathrm{NH}_{4} \mathrm{H}_{2} \mathrm{PO}_{4}, 0.1 \mathrm{mM} \mathrm{MgSO}_{4} \times 7 \mathrm{H}_{2} \mathrm{O}, 4.63 \mathrm{mM} \mathrm{H}_{3} \mathrm{BO}_{3}, 0.91 \mathrm{mM}$ $\mathrm{MnCl}_{2} \times 4 \mathrm{H}_{2} \mathrm{O}, 0.03 \mathrm{mM} \mathrm{CuSO}_{4} \times 5 \mathrm{H}_{2} \mathrm{O}, 0.06 \mathrm{mM} \mathrm{H}_{2} \mathrm{MoO}_{4} \times \mathrm{H}_{2} \mathrm{O}, 0.16 \mathrm{mM} \mathrm{ZnSO}_{4} \times 7 \mathrm{H}_{2} \mathrm{O}$, $1.64 \mathrm{mM} \mathrm{FeSO}_{4} \times 7 \mathrm{H}_{2} \mathrm{O}$, and $0.81 \mathrm{mM} \mathrm{Na}_{2}$-EDTA. Nutrient solution was refreshed every other day and aerated continuously. The seedlings were grown in a growth chamber under controlled environmental conditions: photoperiod 16/8 h (light/dark), $250 \mu \mathrm{mol} \mathrm{m}^{-2} \mathrm{~s}^{-1}$ photosynthetic photon flux density (PPFD), $26 / 22{ }^{\circ} \mathrm{C}$ day/night temperature and $60-65 \%$ relative air humidity. Nutrient solutions were refreshed every other day and aerated continuously. When plants were 8 days old, they were exposed to the high $\mathrm{Cd}$ and $\mathrm{Zn}$ concentrations in the nutrient solution for 7 days. The experimental design included 3 treatments: (1) unexposed seedlings (control), (2) seedlings exposed to $50 \mu \mathrm{M} \mathrm{Cd}^{2+}$ $\left(3 \mathrm{CdSO}_{4} \times 8 \mathrm{H}_{2} \mathrm{O}\right)$ and (3) seedlings exposed to $600 \mu \mathrm{M} \mathrm{Zn}^{2+}\left(\mathrm{ZnSO}_{4} \times 7 \mathrm{H}_{2} \mathrm{O}\right)$. These concentrations were chosen based on preliminary dose-response experiments. At the end of experimental period, wheat plants were used for different analyses.

Dry weight of the plants was determined after drying them for $24 \mathrm{~h}$ at $65{ }^{\circ} \mathrm{C}$. Relative growth rates (RGR) of the plants from different treatments were calculated according to Beadle [65]. $\mathrm{RGR}=\left(\operatorname{lnDW}_{2}-\operatorname{lnDW_{1}}\right) / t$, where $\mathrm{DW}_{2}$ and $\mathrm{DW}_{1}$ stand for final and initial weights of the plants and $\mathrm{t}$ - experimental period ( 7 days).

Total contents of $\mathrm{Cd}$ and $\mathrm{Zn}$ in roots and leaves were determined by inductively coupled plasma-atomic emission spectroscopy (ICP-AES) after dry mineralization at $500{ }^{\circ} \mathrm{C}$ preceded by $\mathrm{HNO}_{3}$ treatment.

Net photosynthetic rate (A) was measured on the second developed leaf of the plants with an open photosynthetic system LCA-4 (Analytical Development Company Ltd., Hoddesdon, UK), equipped with a narrow chamber at the experimental conditions described above.

Photosynthetic pigments (chlorophyll $a$, chlorophyll $b$ and total carotenoids) were extracted in $80 \%$ acetone, determined spectrophotometrically, and calculated according to the formulae of Lichtenthaler [66].

Chlorophyll fluorescence analysis was performed using a Handy PEA fluorimeter (Handy Plant Efficiency Analyzer, Hansatech Instruments Ltd., King's Lynn, UK) on native leaves of plants 7 days after start of the treatment (DAT). The whole plants were adapted to darkness in room for $1 \mathrm{~h}$ and additionally the measured spots were kept in darkness in the clip for $1 \mathrm{~min}$ just before measurement. Induction curves of ChlF were recorded for $1 \mathrm{~s}$ with $3000 \mu \mathrm{mol} \mathrm{m}{ }^{-2} \mathrm{~s}^{-1}$ PPFD. For each experimental treatment, at least 10 measurements were performed. The primary data processing was done using the HandyBarley program, developed by Petko Chernev at the Department of Biophysics and Radiobiology, Faculty of Biology, Sofia University, and the secondary processing, including calculation of JIP parameters-on Microsoft Excel. The plots were made in Sigma Plot.

The intensity of the ChlF was recorded in arbitrary units. Those were transformed into relative units of the relative variable chlorophyll fluorescence $\left(\mathrm{V}_{t}\right)$ by double normalization to the initial, minimum level, $\mathrm{F}_{\mathrm{O}}$, and to the maximum level, $\mathrm{F}_{\mathrm{M}}$. When the $\mathrm{V}_{\mathrm{t}}$ values of the untreated control were subtracted from the values of the other treatments at the corresponding moment in the induction time, the differential curves were built. For more detailed analysis of the processes occurring within the induction time, the chlorophyll fluorescence rise was analyzed within 4 time intervals and differential curves were constructed for each of them. Such curves were made by double normalization to: $\mathrm{F}_{\mathrm{O}}$ and $\mathrm{F}_{\mathrm{J}}$ (level at $2 \mathrm{~ms}$ ), $\mathrm{F}_{\mathrm{O}}$ and $\mathrm{F}_{\mathrm{K}}$ (at $0.3 \mathrm{~ms}$ ), $\mathrm{F}_{\mathrm{J}}$ and $\mathrm{F}_{\mathrm{I}}$ (at $30 \mathrm{~ms}$ ) and $\mathrm{F}_{\mathrm{I}}$ and $\mathrm{F}_{\mathrm{P}}$. 
Table 3. Definitions of measured and calculated chlorophyll $a$ fluorescence parameters used in the experiment (Based on $[49,55,56,58,67])$.

\begin{tabular}{|c|c|}
\hline Chlorophyll Fluorescence Parameter & Description \\
\hline \multicolumn{2}{|c|}{ Measured parameters and basic JIP-test parameters derived from the OJIP transient } \\
\hline $\mathrm{F}_{\mathrm{O}} \sim \mathrm{F}_{20 \mu \mathrm{s}}$ & Minimum fluorescence, when all PSII reaction centers (RCs) are open; Fluorescence intensity at $20 \mu \mathrm{s}$ \\
\hline $\mathrm{F}_{\mathrm{J}}$ & Fluorescence at the J-step ( $2 \mathrm{~ms}$ ) of the O-J-I-P transient \\
\hline $\mathrm{F}_{\mathrm{I}}$ & Fluorescence at the I-step (30 ms) of the O-J-I-P transient \\
\hline$F_{M}=F_{P}$ & Maximum recorded fluorescence at the P-step when all RCs are closed \\
\hline $\mathrm{t}\left(\mathrm{F}_{\mathrm{M}}\right)$ & Time (in ms) to reach maximal fluorescence $\mathrm{F}_{\mathrm{M}}$ \\
\hline $\mathrm{M}_{0}=4 \times\left[\left(\mathrm{F}_{300 \mu \mathrm{s}}-\mathrm{F}_{50 \mu \mathrm{s}}\right) /\left(\mathrm{F}_{\mathrm{M}}-\mathrm{F}_{50 \mu \mathrm{s}}\right)\right]$ & Approximated initial slope (in $\mathrm{ms}^{-1}$ ) of the fluorescent transient. This parameter is related to the rate of closure of reaction centers \\
\hline $\mathrm{N}=\mathrm{S}_{\mathrm{m}} / \mathrm{S}_{\mathrm{s}}=\mathrm{S}_{\mathrm{m}} \times \mathrm{M}_{0} \times\left(1 / \mathrm{V}_{\mathrm{J}}\right)$ & $\begin{array}{l}\text { Turnover number: number of } Q_{A} \text { reduction events between } t=0 \text { and } t\left(\mathrm{~F}_{\mathrm{M}}\right) \text {, where } \mathrm{S}_{\mathrm{m}} \text { is normalized total complementary area above the } \\
\text { O-J-I-P transient (reflecting multiple-turnover } \mathrm{Q}_{\mathrm{A}} \text { reduction events), } \mathrm{S}_{\mathrm{s}}-\text { normalized total complementary area corresponding only to the } \\
\text { O-J phase (reflecting single-turnover } \mathrm{Q}_{\mathrm{A}} \text { reduction events) and } \mathrm{V}_{\mathrm{J}}-\text { relative variable fluorescence at the J-step }\end{array}$ \\
\hline \multicolumn{2}{|l|}{ Specific energy fluxes (per active, i.e., $\mathrm{Q}_{\mathrm{A}}$-reducing PSII RC) } \\
\hline $\mathrm{ABS} / \mathrm{RC}=\mathrm{M}_{0} \times\left(1 / \mathrm{V}_{\mathrm{J}}\right) \times\left(1 / \phi_{\mathrm{Po}}\right)$ & Absorption flux per RC corresponding directly to its apparent antenna size-ratio between chlorophyll in antenna and chlorophyll in RC \\
\hline $\mathrm{DI}_{0} / \mathrm{RC}=(\mathrm{ABS} / \mathrm{RC})-\left(\mathrm{TR}_{0} / \mathrm{RC}\right)$ & Dissipated energy flux per RC at the initial moment of the measurement, i.e., at $\mathrm{t}=0$ \\
\hline $\mathrm{TR}_{0} / \mathrm{RC}=\mathrm{M}_{0} \times\left(1 / \mathrm{V}_{\mathrm{J}}\right)$ & Trapping flux leading to $\mathrm{Q}_{\mathrm{A}}$ reduction per $\mathrm{RC}$ at $\mathrm{t}=0$ \\
\hline $\mathrm{ET}_{0} / \mathrm{RC}=\mathrm{M}_{0} \times\left(1 / \mathrm{V}_{\mathrm{J}}\right) \times\left(1-\mathrm{V}_{\mathrm{J}}\right)$ & Electron transport flux from $\mathrm{Q}_{\mathrm{A}}{ }^{-}$to plastoquinone per $\mathrm{RC}$ at $\mathrm{t}=0$ \\
\hline $\mathrm{RE}_{0} / \mathrm{RC}=\mathrm{M}_{0} \times\left(1 / \mathrm{V}_{\mathrm{J}}\right) \times\left(1-\mathrm{V}_{\mathrm{I}}\right)$ & Electron transport flux from $\mathrm{Q}_{\mathrm{A}}{ }^{-}$to the PSI end electron acceptors per $\mathrm{RC}$ at $\mathrm{t}=0$, where $\mathrm{V}_{\mathrm{I}}$ is the relative variable fluorescence at the I-step \\
\hline \multicolumn{2}{|l|}{ Density of reaction centers } \\
\hline $\mathrm{RC} / \mathrm{CS}_{0}=\phi_{\mathrm{Po}} \times\left(\mathrm{V}_{\mathrm{J}} / \mathrm{M}_{0}\right) \times \mathrm{F}_{\mathrm{O}}$ & Density of active PSII RCs. CS denotes cross section \\
\hline \multicolumn{2}{|l|}{ Quantum yields and probabilities } \\
\hline$\gamma_{\mathrm{RC}}=1 /[(\mathrm{ABS} / \mathrm{RC})+1]=\mathrm{RC} /(\mathrm{ABS}+\mathrm{RC})$ & Probability that PSII chlorophyll molecule functions as RC \\
\hline$\phi_{\mathrm{Po}}=\mathrm{TR}_{0} / \mathrm{ABS}=\left[1-\left(\mathrm{F}_{\mathrm{O}} / \mathrm{F}_{\mathrm{M}}\right)\right]$ & Maximum quantum yield of primary PSII photochemistry $(a t t=0)$ \\
\hline$\psi_{0}=\mathrm{ET}_{0} / \mathrm{TR}_{0}=1-\mathrm{V}_{\mathrm{J}}$ & Probability $\left(\right.$ at $\mathrm{t}=0$ ) that a trapped exciton moves an electron into the electron transport chain beyond $\mathrm{Q}_{\mathrm{A}}{ }^{-}$ \\
\hline$\phi_{\mathrm{Eo}}=\mathrm{ET}_{0} / \mathrm{ABS}=\phi_{\mathrm{Po}} \times \psi_{\mathrm{Eo}}$ & Quantum yield (at $\mathrm{t}=0$ ) for electron transport from $\mathrm{Q}_{\mathrm{A}}{ }^{-}$to plastoquinone \\
\hline$\delta_{\mathrm{Ro}_{0}}=\mathrm{RE}_{0} / \mathrm{ET}_{0}=\left(1-\mathrm{V}_{\mathrm{I}}\right) /\left(1-\mathrm{V}_{\mathrm{J}}\right)$ & $\begin{array}{l}\text { Efficiency / probability }(a t t=0) \text { with which an electron from the intersystem carriers moves to reduce end electron acceptors at the PSI } \\
\text { acceptor side }\end{array}$ \\
\hline$\phi_{\mathrm{Ro}}=\mathrm{RE}_{0} / \mathrm{ABS}=\phi_{\mathrm{Eo}} \times \delta_{\mathrm{Ro}}$ & Quantum yield $(a t \mathrm{t}=0$ ) for reduction of end electron acceptors at the PSI acceptor side \\
\hline \multicolumn{2}{|l|}{ Performance indexes } \\
\hline $\mathrm{PI}_{\mathrm{ABS}}=\gamma_{\mathrm{RC}} /\left(1-\gamma_{\mathrm{RC}}\right) \times \phi_{\mathrm{Po}} /\left(1-\phi_{\mathrm{Po}}\right) \times \psi_{\mathrm{Eo}} /\left(1-\psi_{\mathrm{Eo}}\right)$ & Performance index of PSII based on absorption \\
\hline $\mathrm{PI}_{\text {total }}=\mathrm{PI}_{\mathrm{ABS}} \times \delta_{\mathrm{Ro}} /\left(1-\delta_{\mathrm{Ro}}\right)$ & Performance index of electron flux to the final PSI electron acceptors, i.e., of both PSII and PSI \\
\hline
\end{tabular}


The chlorophyll fluorescence intensity values determined at $50 \mu \mathrm{s}, 100 \mu \mathrm{s}$, and $300 \mu \mathrm{s}$, along with $\mathrm{F}_{\mathrm{O}}, \mathrm{F}_{\mathrm{J}}, \mathrm{F}_{\mathrm{I}}$, and $\mathrm{F}_{\mathrm{M}}$ were used for the calculation of the OJIP test parameters $[49,55,56,58,67]$, which are presented in Table 3.

Statistical analysis of physiological parameters was performed using a one-way ANOVA (for $p<0.05$ ). Based on ANOVA results, a Tukey's test for main comparison at a 95\% confidential level was applied. Statistical analysis for ChlF parameters was performed with the program Sigma Plot version 11 using one-way ANOVA and the Holm-Sidak method for multiple comparisons with overall significance level of 0.05 .

Author Contributions: Andon Vassilev, Jaco Vangronsveld and Vasilij Goltsev conceived and designed the experiments. Lyubka Koleva and Momchil Paunov performed experiments and analyses. All authors contributed to the writing of the paper.

Conflicts of Interest: The authors declare no conflict of interest.

\section{References}

1. Vassilev, A.; Schwitzguébel, J.-P.; Thewys, T.; van der Lelie, D.; Vangronsveld, J. The use of plants for remediation of metal-contaminated soils. Sci. World J. 2004, 4, 9-34. [CrossRef] [PubMed]

2. Rout, G.R.; Das, P. Effect of Metal Toxicity on Plant Growth and Metabolism: I. Zinc. In Sustainable Agriculture; Lichtfouse, E., Navarrete, M., Debaeke, P., Véronique, S., Alberola, C., Eds.; Springer: Dordrecht, The Netherlands, 2009; pp. 873-884.

3. Grant, C.A.; Buckley, W.T.; Bailey, L.D.; Selles, F. Cadmium accumulation in crops. Can. J. Plant Sci. 1998, 78, 1-17. [CrossRef]

4. Koleva, L.; Staneva, D.; Yordanova, I.; Bineva, T.; Vassilev, A. Characterization of cadmum uptake by roots of durum wheat plants. JCEA 2008, 9, 533-538.

5. Tang, L.; Aijun, Y.; Ming, Y.; Yetao, T.; Xi, L.; Rongliang, Q. Transcriptional up-regulation of genes involved in photosynthesis of the $\mathrm{Zn} / \mathrm{Cd}$ hyperaccumulator Sedum alfredii in response to zinc and cadmium. Chemosphere 2016, 164, 190-200. [CrossRef] [PubMed]

6. Poschenrieder, Ch.; Tolra, R.; Barcelo, J. Can metals defend plants against biotic stress? Trends Plant Sci. 2006, 11, 288-295. [CrossRef] [PubMed]

7. Broadley, M.R.; White, P.J.; Hammond, J.P.; Zelko, I.; Lux, A. Zinc in plants. New Phytol. 2007, 173, 677-702. [CrossRef] [PubMed]

8. Vassilev, A.; Perez-Sanz, A.; Cuypers, A.; Vangronsveld, J. Tolerance of two hydroponically grown Salix genotypes to excess Zn. J. Plant Nutr. 2007, 30, 1472-1482. [CrossRef]

9. Vangronsveld, J.; Clijsters, H. Toxic effects of metals. In Plants and the Chemical Elements. Biochemistry, Uptake, Tolerance and Toxicity; Farago, M.E., Ed.; VCH Publishers: Weinheim, Germany, 1994; pp. 150-177.

10. Vassilev, A.; Yordanov, I. Reductive analysis of factors limiting growth of cadmium-treated plants: A review. Bulg. J. Plant Physiol. 1997, 23, 114-133.

11. Clijsters, H.; Van Assche, F. Inhibition of photosynthesis by heavy metals. Photosynth. Res. 1985, 7, 31-40. [CrossRef] [PubMed]

12. Van Assche, F.; Clijsters, H. Effects of metals on enzyme activity in plants. Plant, Cell and Environment 1990, 13, 195-206. [CrossRef]

13. Barceló, J.; Poschenrieder, C. Plant water relations as affected by heavy metal stress: A review. J. Plant Nutr. 1990, 13, 1-37. [CrossRef]

14. Chaney, R. Zinc phytotoxicity. In Zinc in Soils and Plants; Robson, A.D., Ed.; Kluwer Academic Publisher: Dordrecht, The Netherlands, 1993; pp. 135-150.

15. Siedlecka, A. Some aspects of interactions between heavy metals and plant mineral nutrients. Acta Soc. Bot. Pol. 1995, 64, 265-272. [CrossRef]

16. Cuypers, A.; Smeets, K.; Vangronsveld, J. Heavy Metal Stress in Plants. In Plant Stress Biology: From Genomics to Systems Biology; Hirt, H., Ed.; Wiley-VCH Verlag GmbH \& Co. KGaA: Weinheim, Germany, 2009. [CrossRef]

17. Krupa, Z. Cadmium against Higher Plant Photosynthesis—A Variety of Effects and Where Do They Possibly Come From? Z. Naturforsch. 1999, 54c, 723-729. [CrossRef] 
18. Cuypers, A.; Vangronsve, J.; Clijsters, H. The redox status of plant cells (AsA and GSH) is sensitive to zinc imposed oxidative stress in roots and primary leaves of Phaseolus vulgaris. Plant Physiol. Biochem. 2001, 39, 657-664. [CrossRef]

19. Vassilev, A.; Nikolova, A.; Koleva, L.; Lidon, F. Effects of Excess Zn on Growth and Photosynthetic Performance of Young Bean Plants. J. Phytol. 2011, 3, 58-62.

20. Van Assche, F.V.; Clijsters, H. Inhibition of photosynthesis by treatment of Phaseolus vulgaris with toxic concentration of zinc: Effects on electron transport and photophosphorylation. Physiol. Plant. 1986, 66, 717-721. [CrossRef]

21. Vassilev, A.; Manolov, P. Chlorophyll fluorescence of barley (H. vulgare L.) seedlings grown in excess of Cd. Bulg. J. Plant Physiol. 1999, 25, 67-76.

22. Kalaji, H.M.; Loboda, T. Photosystem II of barley seedlings under cadmium and lead stress. Soil Environ. 2007, 53, 511-516. [CrossRef]

23. Sagardoy, R.; Morales, F.; López-Millán, A.F.; Abadía, A.; Abadía, J. Effects of zinc toxicity on sugar beet (Beta vulgaris L.) plants grown in hydroponic. Plant Biol. 2009, 11, 339-350. [CrossRef] [PubMed]

24. Vassilev, A.; Lidon, F.C.; Matos, M.D.; Ramalho, J.C.; Bareiro, M.G. Shoot cadmium accumulation and photosynthetic performance of barley at high Cd treatments. J. Plant Nutr. 2004, 27, 773-793. [CrossRef]

25. Krupa, Z.; Öquist, G.; Huner, N.P.A. The effects of cadmium on photosynthesis of Phaseolus vulgarisA fluorescence analysis. Physiol. Plant. 1993, 88, 626-630. [CrossRef] [PubMed]

26. Vassilev, A.; Lidon, F.C.; Scotti, P.; da Graca, M.; Yordanov, I. Cadmium-induced changes in chloroplast lipids and photosystem activities of barley plants. Biol. Plant. 2004, 48, 153-156. [CrossRef]

27. Cuypers, A.; Remans, T.; Weyens, N.; Colpaert, J.; Vassilev, A.; Vangronsveld, J. Soil plant relationships of metals and metalloids (Chapter 6). In Heavy Metals in Soils: Trace Metals and Metalloids in Soils and Their Bioavailability, 3rd ed.; Environmental Pollution Series; Alloway, B., Ed.; Springer Verlag: Berlin, Germany, 2012; pp. 161-195, ISBN 978-94-007-4469-1.

28. Lazár, D. Parameters of photosynthetic energy partitioning. J. Plant Physiol. 2015, 175, 131-147. [CrossRef] [PubMed]

29. Strasser, R.J.; Srivastava, A.; Govindjee. Polyphasic chlorophyll a fluorescent transient in plants and cyanobacteria. Photochem. Photobiol. 1995, 61, 32-42. [CrossRef]

30. Goltsev, V.N.; Kalaji, H.M.; Paunov, M.; Baba, W.; Horaczek, T.; Mojski, J.; Kociel, H.; Allakhverdiev, S.I. Variable Chlorophyll Fluorescence and Its Use for Assessing Physiological Condition of Plant Photosynthetic Apparatus. Russ. J. Plant Physiol. 2017, 63, 869-893. [CrossRef]

31. Kalaji, M.H.; Goltsev, V.N.; Żuk-Gołaszewska, K.; Zivcak, M.; Brestic, M. Chlorophyll Fluorescence: Understanding Crop Performance-Basics and Applications; CRC Press, T\&F Group: Abingdon, UK, 2017; p. 222, ISBN 9781498764490.

32. Kalaji, M.H.; Jajoo, A.; Oukarroum, A.; Brestic, M.; Zivcak, M.; Samborska, I.A.; Cetner, M.D.; Łukasik, I.; Goltsev, V.; Ladle, R.J. Chlorophyll a fluorescence as a tool to monitor physiological status of plants under abiotic stress conditions. Acta Physiol. Plant. 2016, 38, 1-11. [CrossRef]

33. Kalaji, M.H.; Schansker, G.; Brestic, M.; Bussotti, F.; Calatayud, A.; Ferroni, L.; Goltsev, V.; Guidi, L.; Jajoo, A.; Li, P.; et al. Frequently asked questions about chlorophyll fluorescence, the sequel. Photosynth. Res. 2017, 132, 13-66. [CrossRef] [PubMed]

34. Stirbet, A.; Lazár, D.; Kromdijk, J. Chlorophyll a fluorescence induction: Can just a one-second measurement be used to quantify abiotic stress responses? Photosynthetica 2018, 1-19. [CrossRef]

35. Luttge, U. Light-stress and crassulacean acid metabolism. Phyton 2000, 40, 65-82.

36. Krause, G.H. Photoinhibition induced by low temperatures. In Photoinhibition of Photosynthesis. Environmental Plant Biology; Baker, N.R., Bowyer, J.R., Eds.; BIOS Scientific Publishers Ltd.: Oxford, UK, 1994; pp. 331-348.

37. Koscielniak, J.; Biesaga-Koscielniak, J. Effects of exposure to short periods of suboptimal temperature during chili (5 degrees C) on gas exchange and chlorophyll fluorescence in maize seedlings (Zea mays L.). J. Agron. Crop. Sci. 1999, 183, 231-241. [CrossRef]

38. Georgieva, K.; Yordanov, I. Temperature dependence of chlorophyll fluorescence parameters of pea seedlings. J. Plant Physiol. 1993, 142, 151-155. [CrossRef]

39. Srivastava, A.; Strasser, R.J. Regulation of antenna structure and electron transport in Photosystem II of Pisum sativum under elevated temperature probed by the fast polyphasic chlorophyll a fluorescence transient: OKJIP. Biochim. Biophys. Acta 1997, 1320, 95-106. [CrossRef] 
40. Bukhov, N.; Carpentier, R. Heterogeneity of photosystem II reaction centers as influenced by heat treatment of barley leaves. Physiol. Plant. 2000, 110, 279-285. [CrossRef]

41. Oukarroum, A.; Madidi, S.E.; Schansker, G.; Strasser, R.J. Probing the responses of barley cultivars (Hordeum vulgare L.) by chlorophyll a fluorescence OLKJIP under drought stress and re-watering. Environ. Exp. Bot. 2007, 60, 438-446. [CrossRef]

42. Georgieva, K.; Maslenkova, L.; Peeva, V.; Markovska, Y.; Stefanov, D.; Tuba, Z. Comparative study on the changes in photosynthetic activity of the homoiochlorophyllous desiccation-tolerant Haberlea rhodopensis and desiccation-sensitive spinach leaves during desiccation and rehydration. Photosynth. Res. 2005, 85, 191-203. [CrossRef] [PubMed]

43. Georgieva, K.; Szigeti, Z.; Sarvari, E.; Gaspar, L.; Maslenkova, L.; Peeva, V.; Peli, E.; Tuba, Z. Photosynthetic activity of homoiochlorophyllous desiccation tolerant plant Haberlea rhodopensis during dehydration and rehydration. Planta 2007, 225, 955-964. [CrossRef] [PubMed]

44. Goltsev, V.; Zaharieva, I.; Chernev, P.; Kouzmanova, M.; Kalaji, H.M.; Yordanov, I.; Krasteva, V.; Alexandrov, V.; Stefanov, D.; Allakhverdiev, S.I.; et al. Drought-induced modifications of photosynthetic electron transport in intact leaves: Analysis and use of neural networks as a tool for a rapid non-invasive estimation. Biochim. Biophys. Acta 2012, 1817, 1490-1498. [CrossRef] [PubMed]

45. Li, Q.; Chen, L.-S.; Jiang, H.-X.; Tang, N.; Yang, L.-T.; Lin, Z.-H.; Li, Y.; Yang, G.-H. Effects of manganese-excess on $\mathrm{CO}_{2}$ assimilation, ribulose-1,5-bisphosphate carboxylase/oxygenase, carbohydrates and photosynthetic electron transport of leaves, and antioxidant systems of leaves and roots in Citrus grandis seedlings. BMC Plant Biol. 2010, 10, 42. [CrossRef] [PubMed]

46. Zurek, G.; Rybka, K.; Pogrzeba, M.; Krzyżak, J.; Prokopiuk, K. Chlorophyll a Fluorescence in Evaluation of the Effect of Heavy Metal Soil Contamination on Perennial Grasses. PLoS ONE 2014, 9, e91475. [CrossRef] [PubMed]

47. Cuchiara, C.C.; Silva, I.M.C.; Martinazzo, E.G.; Braga, E.J.B.; Bacarin, M.A.; Peters, J.A. Chlorophyll Fluorescence Transient Analysis in Alternanthera tenella Colla Plants Grown in Nutrient Solution with Different Concentrationsof Copper. J. Agric. Sci. 2013, 5, 8-16.

48. Franić, M.; Galić, V.; Mazur, M.; Šimić, D. Effects of excess cadmium in soil on JIP-test parameters, hydrogen peroxide content and antioxidant activity in two maize inbreds and their hybrid. Photosynthetica 2017, 55, 1-10. [CrossRef]

49. Tsimilli-Michael, M.; Strasser, R.J. In vivo assessment of stress impact on plant's vitality: Applications in detecting and evaluating the beneficial role of Mycorrhization on hostplants. In Mycorrhiza: State of the Art, Genetics and Molecular Biology, Eco-Function, Biotechnology, Eco-Physiology, Structure and Systematics, 3rd ed.; Varma, A., Ed.; Springer Verlag: Berlin/Heidelberg, Germany, 2008; pp. 679-703.

50. Lazár, D. The polyphasic chlorophyll a fluorescence rise measured under high intensity of exciting light. Funct. Plant Biol. 2006, 33, 9-30. [CrossRef]

51. Havaux, M. Characterization of thermal damage to the photosynthetic electron transport system in potato leaves. Plant Sci. 1993, 94, 19-33. [CrossRef]

52. Yamane, Y.; Kashino, Y.; Koike, H.; Satoh, K. Effects of high temperatures on photosynthetic systems in higher plants. In Photosynthesis: From Light to Biosphere; Mathis, P., Ed.; Kluwer Academic Publishers: Dordrecht, The Netherlands, 1995; Volume 5, pp. 849-852.

53. Strasser, B. Donor side capacity of Photosystem II probed by chlorophyll a fluorescence transients. Photosynth. Res. 1997, 52, 147-155. [CrossRef]

54. Steffen, R.; Eckert, H.-J.; Kelly, A.A.; Dörmann, P.; Renger, G. Investigations on the reaction pattern of photosystem II in leaves from Arabidopsis thaliana by time-resolved fluorometric analysis. Biochemistry-US 2005, 44, 3123-3133. [CrossRef] [PubMed]

55. Strasser, R.J.; Tsimilli-Michael, M.; Qiang, S.; Goltsev, V. Simultaneous in vivo recording of prompt and delayed fluorescence and 820-nm reflection changes during drying and after rehydration of the resurrection plant Haberlea rhodopensis. Biochim. Biophys. Acta 2010, 1797, 1313-1326. [CrossRef] [PubMed]

56. Strasser, R.J.; Tsimilli-Michael, M.; Srivastava, A. Analysis of the chlorophyll $a$ fluorescence transient. In Chlorophyll a Fluorescence: A Signature of Photosynthesis. Advances in Photosynthesis and Respiration; Papageorgiou, G., Govindjee, Eds.; Springer: Dordrecht, The Netherlands, 2004; Volume 19, pp. 321-362.

57. Joliot, A.; Joliot, P. Etude cinetique de la reaction photochimique liberant loxygene au cours de la photosynthese. Comptes Rendus Acad. Sci. 1964, 258, 4622. 
58. Tsimilli-Michael, M.; Strasser, R. The energy flux theory 35 years later: Formulations and applications. Photosynth. Res. 2013, 117, 289-320. [CrossRef] [PubMed]

59. Strasser, R.J.; Stirbet, A. Heterogeneity of photosystem II probed by the numerically simulated chlorophyll a fluorescence rise (O-J-I-P). Math. Comput. Simul. 1998, 48, 3-9. [CrossRef]

60. Lazár, D.; Pospíšil, P.; Nauš, J. Decrease of fluorescence intensity after the K step in chlorophyll a fluorescence induction is suppressed by electron acceptors and donors to photosystem 2. Photosynthetica 1999, 37, 255-265. [CrossRef]

61. Strasser, R.J.; Greppin, H. Primary reactions of photochemistry in higher plants. In Photosynthesis: Structure and Molecular Organisation of the Photosynthetic Apparatus; Akoyunoglou, G., Ed.; Balaban International Science Services: Philiadelphia, PA, USA, 1981; Volume III, pp. 717-726.

62. Strasser, R.J. The grouping model of plant photosynthesis: Heterogeneity of photosynthetic units in thylakoids. In Photosynthesis: Structure and Molecular Organisation of the Photosynthetic Apparatus; Akoyunoglou, G., Ed.; Balaban International Science Services: Philiadelphia, PA, USA, 1981; Volume III, pp. 727-737.

63. Guisse, B.; Srivastava, A.; Strasser, R.J. Effects of high temperature and water stress on the polyphasic chlorophyll a fluorescence transient of potato leaves. In Photosynthesis: From Light to Biosphere; Mathis, P., Ed.; Kluwer Academic Publishers: Dordrecht, The Netherlands, 1995; pp. 913-916.

64. De Ronde, J.A.; Cress, W.A.; Krüger, G.H.J.; Strasser, R.J.; Van Staden, J. Photosynthetic response of transgenic soybean plants, containing an Arabidopsis P5CR gene, during heat and drought stress. J. Plant Physiol. 2004, 161, 1211-1224. [CrossRef] [PubMed]

65. Beadle, C.L. Growth analysis. In Photosynthesis and Production in a Changing Environment: A Field and Laboratory Manual; Scurlock, J.M.O., Bolhàr-Nordenkampf, H.R., Leegood, R.C., Long, S.P., Hall, D.O., Eds.; Springer Science \& Business Media: Dordrecht, The Netherlands, 1993; pp. 36-46.

66. Lichtenthaler, H.K. Chlorophylls and carotenoids: Pigments of photosynthetic biomembrans. Methods Enzymol. 1987, 148, 350-382.

67. Strasser, R.J.; Srivastava, A.; Tsimilli-Michael, M. The fluorescence transient as a tool to characterize and screen photosynthetic samples. In Probing Photosynthesis: Mechanism, Regulation $\mathcal{E}$ Adaptation; Yunus, M., Pathre, U., Eds.; Taylor \& Francis: London, UK, 2000; pp. 443-480.

(c) 2018 by the authors. Licensee MDPI, Basel, Switzerland. This article is an open access article distributed under the terms and conditions of the Creative Commons Attribution (CC BY) license (http:/ / creativecommons.org/licenses/by/4.0/). 